\title{
Cyber Feminism: Unleashing Women Power through Technology
}

\author{
J. R. Mohanty ${ }^{1} \&$ Swati Samantaray ${ }^{2}$ \\ ${ }^{1}$ Professor, School of Computer Applications, KIIT University, Bhubaneswar. ORCID: oooo- \\ ooo2-8762-3037.Email:jnyana1@gmail.com \\ ${ }^{2}$ Associate Professor, School of Humanities, KIIT University, Bhubaneswar. ORCID: oooo- \\ ooo2-4823-9278.Email: swati.sray@gmail.com
}

Received May 11, 2017; Revised July 07, 2017; Accepted July 07, 2017; Published August 06, 2017.

\begin{abstract}
Feminism is an existential struggle to assert one's individuality-it stands for gender equality, independence and empowerment to women. The concept of feminism examines and analyzes gender identity, by way of targeting women's autonomous self-identity. If we enter into the world of cyberspace we find technology is opening up the possibility for female emancipation. Over just two decades, the Internet has worked a thorough revolution and is considered to be a great equalizer; yet, access to it is not uniformly shared. This paper explores what Internet along with the cyberspace signifies to women and how they employ the cyberspace for their personal schedule from a socio-anthropological perspective. Cyber feminism is basically involved with countering the recognized and accepted domination of men in the employment and advancement of information and communication technology (ICT) and cyberspace. The image of technology needs to change to incorporate a female view.
\end{abstract}

Keywords: Cyberspace, Cyber feminism, female emancipation, Information and communication Technology.

\section{Introduction}

Women's empowerment is a multi-dimensional social process consisting of components like: feeling of self-worth, their right to settle on choices, their right to have ingress to prospects and resources, their right to have the authority to manage and direct their individual lives (both indoors and outdoors), and their propensity to clout the direction of social conversion to fashion a more impartial and just social and economic order, not only nationally but also universally.

Feminism emerged as a worldwide movement seeking to do away with the subordination, oppression, inequalities and injustices women suffer because of their gender. Sushila Singh's article "Recent Trend in Feminist Thought: A Tour de Horizon" stresses on the fact that "...as a philosophy of life, it seeks to discover and change the more subtle and deep-seated causes of women's oppression. It is a concept of 'raising of the consciousness' of an entire culture" (Singh 22). Feminism is an existential struggle to assert one's individuality, through feminist articulation. It stands for gender equality, independence and empowerment to women. The critic Christine Gomez points out some of the recurring themes in the article "New Horizons: Exploring the Possibilities of Feminist Literary Criticism on Indian Writing in English" :

(c) AesthetixMS 2016. This Open Access article is published under a Creative Commons Attribution Non-Commercial 4.0 International License (http://creativecommons.org/licenses/by-nc/4.o/), which permits non-commercial re-use, distribution, and reproduction in any medium, provided the original work is properly cited. For citation use the DOI. For commercial re-use, please contact editor@rupkatha.com. 
". . . woman's struggle for self realization and self definition, woman's quest for her identity, her pursuit of freedom, equality and transcendence, her rebellion and protest against oppression at every level, sex-role stereotyping in society, debates about the double moral standard in society, various aspects of female experience such as domestic violence, rape, pregnancy, abortion, motherhood, being single and so on, the evolving of feminine consciousness out of female experience, the internal conflict and ambivalence of women forced to choose between new 'feminist' goals and traditional 'feminine' goals, between total independence and the need for romantic love and emotional fulfillment, the bonding between women forming a sisterhood or a mother-daughter relationship and the alienation of woman as an outsider, as an object, as the other" (Gomez, 1991).

As a corollary, feminism leads women to re-access and analyze gender identity, with the attention on their autonomous self-identity. Feminists utilise the web as a crucial tool for connecting women all over the world and unleashing women power through the use of technology (Bimber, 2000).

\section{Prelude to Cyber Feminism}

Cyberspace can be entitled as the de facto synonym for the internet. "First coined by William Gibson (1982) and then popularized in his 1984 novel Neuromancer, the term 'cyberspace' became a popular descriptor of the mentally constructed virtual environment within which networked computer activity takes place" (Wall, 2007, 10). Cyberspace might be used as an emblem to describe the non-physical terrain crafted by computers. If we enter into the world of internet or cyberspace we find technology is opening up the possibility for female emancipation (Colley \& Maltby, 2008). Generally speaking, cyber feminism implies feminist appropriation of information and computer technology or ICT. VNS Matrix, an Australian-based feminist group of media artists (Josephine Starrs, Francesca da Rimini, Julianne Pierce and Virginia Barratt) are said to be the first to use the term 'cyber feminism' in the early 1990s. The Toronto-based media artist Nancy Paterson is also associated with the term due to her 1992 essay, 'Cyberfeminism', emphasizing gender diversity and cultural subversion. The British cultural theorist Sadie Plant has been equally credited with coining the term. Cyber feminism is basically involved with countering the recognized and accepted domination of men in the employment and advancement of Internet technology. Cyberspace permits women users to share and/or swop information, interact, engage themselves in recreation and have discussions in social forums, and also to carry out business and loads of other enterprises. "The information galaxy, the cyberspace and the Internet...are no longer viewed as a masculine space and tool as women have not only embraced but also used the cyberspace to negotiate and reframe themselves within existing social structure"(Kuah-Pearce, 2008, p.11). Women are regarded to be the consumer and producers of the cyberspace and the Internet. Cyberspace operates like a sort of social capital enabling the women to forge cyber-social networks and communities to facilitate their ventures and requirements.

\section{Technological analysis based on gender}

The web, as we know has presently become a vital means for connecting women globally. Over just two decades, the Internet has worked a thorough revolution and is considered to be a great equalizer; yet, access to it is not uniformly shared. Gender disputes related to the right to use the Internet have been found in a number of investigations and studies in connection with women. 
There are gender distinctions with respect to access of technologies. Technology is often viewed as masculine. Masculinization of the computer culture is found to be one of the reason why there are less female internet users as compared to the male users. In addition, there is a gender divide in terms of who is involved in the design and production of technology. Males are reported to spend more time online and have higher internet skills than females. Many critics are of the opinion that the reasons behind the gradual fall of women in India toward internet usage are cyber bullying, cyber teasing, cyber harassment and hence less security. Literacy skills are also important for women to read web pages and get information. Some women are technophobes and have fear of using computers -- they should be taught ICT skills. In order to benefit from the digital technology, women must be taught how to use it.

The Internet gender divide is notably salient in countries that are still developing and sets women at peril of being left behind. The skewed gender ratio of India is reflected in its Internet access. As a rising number of citizens are bustling in the country online, and the government is planning to offer Internet connection to all its residents (almost 1.30 billion people), several studies have shown that women are still lagging behind men in Internet accessing. In India and also in the global scenario it has been observed that there is a consistent decline in usage of Internet by women in different segments of society (figure 1, and figure 2).

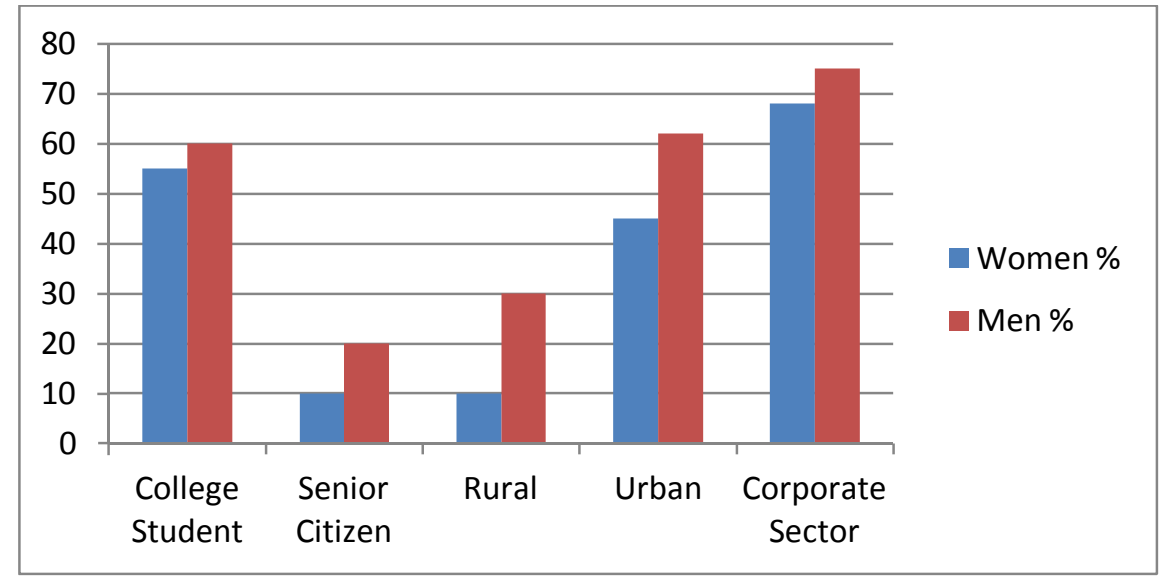

Figure 1. Use of Internet in India (Men Vs Women)

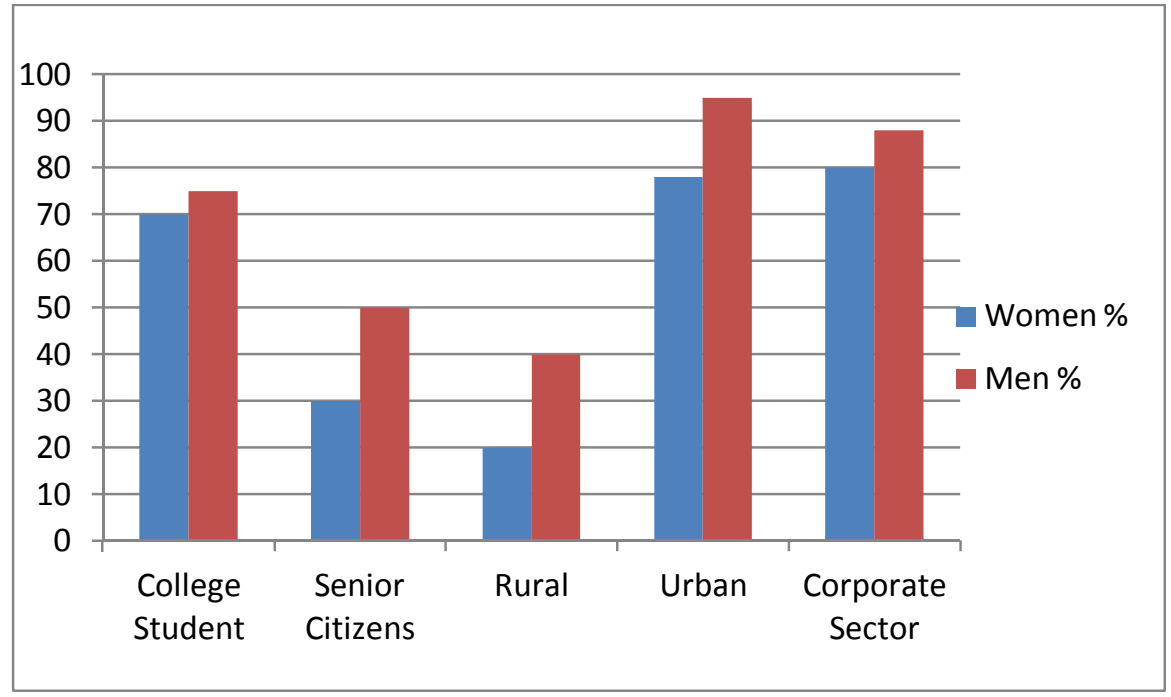

Figure 2. Use of Internet Globally (Men Vs Women) 
One possible clarification of the gender gap is the difference that exists between women and men in connection with the socio-economic status. Since education, job status and income, are associated with the use of Internet, consequently men outnumber women in the ranks of Internet users. Moreover, a great deal has been penned on the subject of gender as well as technology from the standpoint of culture and identity studies, and much of this work advocates that the Internet may have 'gendered' traits that favour men in several ways, regardless of the growth of web sites, chat rooms, and other Internet resources functioning for women. Genderspecific phenomena may contribute to the gender gap on the Internet, provided such claims are true (Bimber, 2000).

Reports say that "with over 462 million Internet users, India is the second largest online market, ranked only behind China. It is expected that the number of internet users may reach 465 million by June 2017. By 2021, there will be about 635.8 million internet users in India. Men are said to dominate Internet usage in India with 71 percent to women's 29 percent" (www.statista.com). Latest reports also project that this gap will reduce in the forthcoming years, that is, by 2020 the share in internet usage by women may reach a $40 \%$ (figure 3). A research work done by tech giant Google and consultancy A.T. Kearney reports that "only one out of every five ecommerce customers in India is a woman. Google predicted that this share could rise from the current $20 \%$ to $40 \%$ in the next four years. The report also mentions that Industry will see a ${ }_{5} \mathrm{X}+$ growth in the number of women shoppers by the year 2020, as top barriers to non-adoption are overcome"(Mukherjee, https://scroll.in).

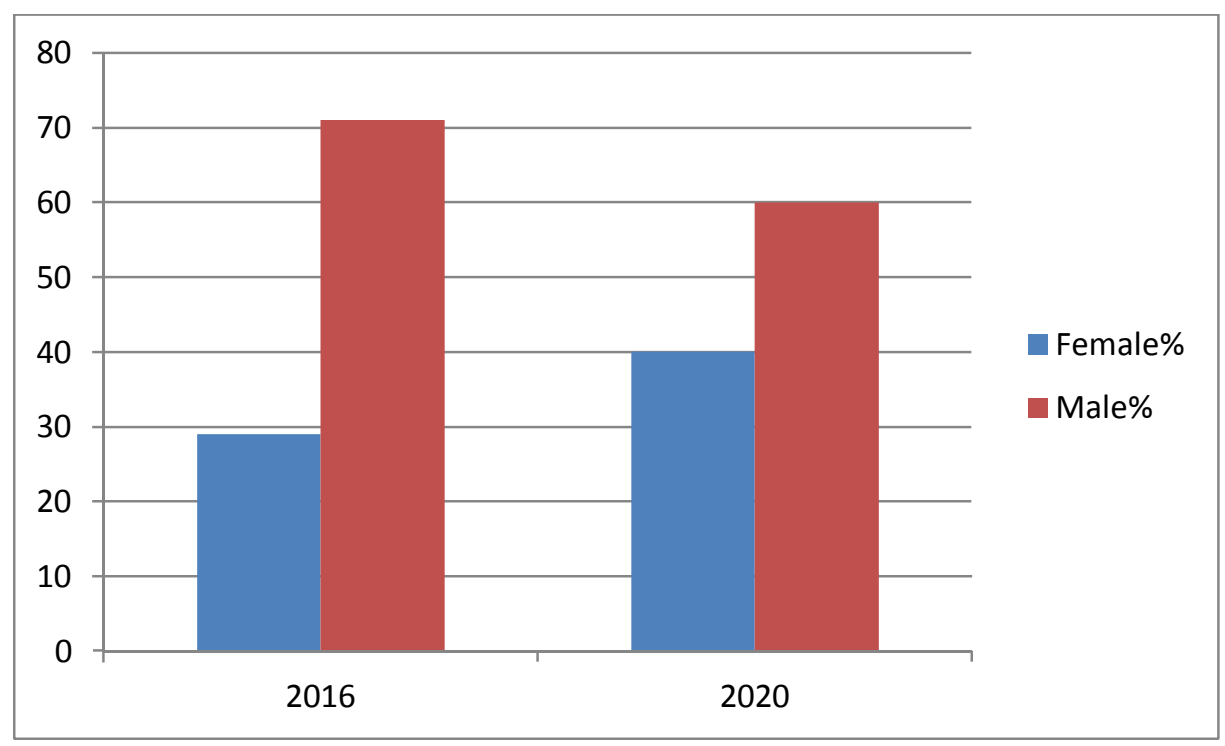

Figure 3. The Percentage of Female and Male Internet Users in India

With regard to female participation on Twitter, the Observer Research Foundation has analysed that "23,350 tweets over an eight-day period and concluded that women are significantly underrepresented in political conversations on the microblogging site, which, it said, reflects their marginalization in political processes in the country as a whole. The report also reflected that $46 \%$ of the tweets in its sample came from men, while less than $8 \%$ were from women. The rest were from organizations and accounts where gender identity could not be accessed or ascertained. Out of the 23,250 tweets sampled under political trending topics, the percentage of women tweets were $7.72 \%$, whereas by the men tweets were $46.15 \%, 34.83 \%$ by organizations, news outlets and other groups, and $11.30 \%$ by users who did not indicate their gender" (Mukherjee, https://scroll.in). While the gender ratio is slightly better in urban India, with 40 per 
cent women using internet as against to 60 per cent men, in rural India only 25 per cent women were internet users as against to 75 per cent men.

Worldwide women tend to lead Internet handling on dominant social networking sites (figure 4); however the tendency is just the opposite within India. The current report of a consultancy firm in UK 'We Are Social' states that on the social networking site - Facebook (which considers India as one of its large-scale markets), the ratio of men to women users is $3: 1$. The Facebook population in India encompasses $76 \%$ men in comparison to just $24 \%$ women; this figure is more gender-skewed with respect to the neighbouring countries Nepal and Bhutan.

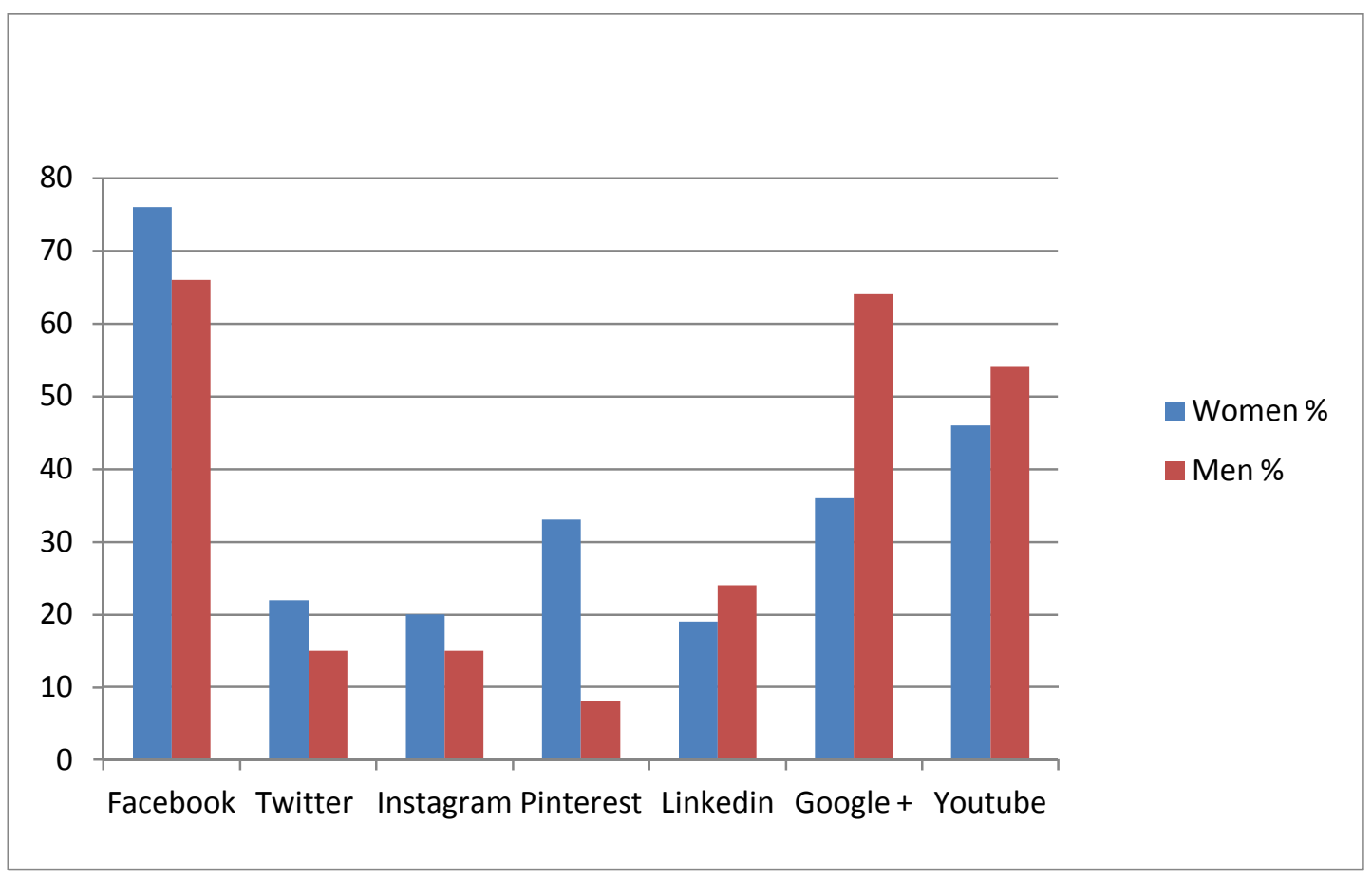

Figure 4. Use of Social Networking Sites Globally (Men Vs Women)

The South Asian nation demonstrate a lopsided use of technology use. Cell phones are the major tools for making the lives of women more attractive in low-income countries and middle-income countries. More than 1.7 billion females in low-income and middle-income countries do not own cell phones:

"More than 440 million, or $72 \%$, of India's females do not have cell phones, according to GSMA, a global association of mobile service companies...More than 100 million fewer women than men have cell phone in India. That is the largest gender gap in the world. India accounts for more than half of the global gap of 200 million women without phones so no other country comes close...Around $43 \%$ of men and $28 \%$ of women own phones in India meaning women are $36 \%$ less likely to own a phone than men... Even when women do have phones, they are often only able to use them for making calls. The GSMA estimates that $55 \%$ of women with phones in India have never even sent a text message. That compares with the $33 \%$ of Indian men with phones who have never sent a text... Just over $80 \%$ of women with phones in India have yet to use their handsets to connect to the internet" (Eric Bellman, https://blogs.wsj.com).

Technology is regarded as a superb equalizer and a mode of getting in touch with people that may not have been possible ever before. Technology condones our skin colour, age, 
disabilities, looks, size, economics and even our gender. Cyber feminism specifies the fact that women are not technophobic (even though this was thought in the past). "Despite its low ranking in knowledge society decision-making and the low rate of females in higher education, India shows a relatively high representation of females in administrative and managerial positions at $28 \%$. Additionally, $28 \%$ of the IT workforce is female - again a high ratio compared to other sectors in the country and to other countries" (Nair, http://www.wisat.org/programs/nationalassessments-on-gender-sti/). According to a report in the year 2015 on an industry ruled by companies like Infosys and Wipro Ltd., around $51 \%$ of entry-level tech sector or IT jobs went to women. Feminism must metamorphose to keep up with the changing complexities of social realities, if it is to be adequate to its cyber potential. It is up to cyber feminists to employ feminist theoretical insights along with strategic tools while linking them with cyber techniques to combat the gender disparity, racism, and militarism programmed in the software and hardware of the Net, hence politicizing the environment eventually.

\section{Critics' Opinion}

Women are usually a target of online trolling. Women occupying space online, especially when it pertains to politically charged matters, are regarded as interlopers in a male space. With regard to gender-based exploitation, several well-known female bloggers and activists have preferred to delete their accounts. Critics are of the opinion that men are deemed the first beneficiaries of innovations, while women pursue them and take over the positions vacated by them. Joshi states that technological work including ICT are often considered as masculine; and the proficiency and control are often in the hands of men. According to Wajcman and Pham Lobb, such assessments hinder women from gaining access to information regarding how to make use of technology. However, women too are considered to play a significant role in the ICT revolution empowerment that transcends stereotype beliefs (Cater-Steel, Aileen \& Emily Cater, 212). The progress of women is hampered by prejudices regarding their ability to learn and to apply new technology. Sadie Plant (a British philosopher and a cultural theorist) in her work Zeroes + Ones, is enthusiastic regarding the potentiality of Internet technologies to metamorphose the lives of women. She conceives cyberspace as a emancipating site for women. According to Sadie:

"The Internet is a quintessentially female technology. First, the values of the Internet, like the free exchange of information, the lessening of hierarchy, and the nurturing aspects of virtual communities, are female values. Second, networking technology is a final proof ... the Internet represents nothing less than the death of patriarchy" (Channa, 181).

The core belief of Zeroes + Ones is that women are liberated by technology and that the current genderquake is just one part of this historical process. Melanie Stewart Millar while discussing about cyber feminism states that it facilitates a women-centered outlook advocating women's utilization of latest information and communications technologies intended for emancipation. Various cyber feminists view these technologies as liberatory in essence and maintain that their progress will lead to an end of male superiority for the reason that women are uniquely suited to life in the digital age. In order to enable women to participate equally, we require Internet that link the digital gender divide and empower women.

\section{Women as Savvy Users}


"Quest for feminine identity is a post-independence social phenomenon" (Samantaray 63). In this connection we may refer to Kapilaben Vankar, a member of the Executive Committee of Self Employed Women's Association (SEWA) who acknowledges how the mobile phone has improved her life:

"I'm a small farmer and I cultivate lily flowers. Every morning I have to pick the flowers and go and sell them in the market. Before (I bought my cell phone through an association loan) I had to move from market to market, from one trader to the other, often spending the entire day in finding a proper market. . . But now I use my cell phone. I call up the different markets while I'm plucking the lily flowers, and by nine in the morning, my flowers reach the market. It saves me tremendous time and also money. I earn almost 1,500 to 2000 rupees as an additional income"

(Burchell, https://www.gsma.com/mobilefordevelopment/ programme/connectedwomen/connected-women-gain-strength).

A huge gender gap exists in the manner technology is employed in India. The sociocultural factors or the sizable forces within cultures and societies often impinge on the mind-set, judgment, and demeanor of individuals. The engagement of girls in house work and domestic chores, patriarchal attitudes and beliefs often restrict women's rights and public spaces, preventing them from accessing Internet centers. We may cite an example here. Google India's digital educative initiative, Internet Saathi programme, is trying to transform lives of women and is aiming to bridge the gender divide in technology through this initiative, which currently puts women in rural India at further risk of getting marginalized in society.

As Asia witnesses growing Internet access across the continent, global conversations (that are determining policies) are popping up on electronic networks, creating fresh knowledge and influencing ideologies. Magazines, E-books, and electronic journals are getting circulated on the World Wide Web; on listservs women are sharing ideas; currently virtual libraries are a reality and movements for social justice are being waged, speeding up the process of activism. Computers help women consumers get entertainment, perform word processing, access the Internet and e-mail for instant digital communications. Computers also aid women for banking and help women access their money at banks and ATMs. They are one of the most important educational tools for women learners and teachers. The Internet opens up different ways for women in order to communicate with others - some of the possible means being social networking sites (Facebook, Twitter, Myspace and the like), e-mail and blogs. Women choose to spend their time online and amuse themselves by reading online books and e-books, watching online videos (YouTube), keeping up-to-date with the news, shopping online and playing online games. Internet has also created opportunities for women who are interested in working online as freelancers. In many ways, technology has helped women balance family, work and outside interests in a better way. Women are naturally able to integrate technology into daily activities. They make use of work-from-home and telecommuting options. Access to information -- a critical tool for social transformation and development -- may be considered as a basic human right for women. For empowering women in the tech sector, we need education as well as requisite skills for the digital world in conjunction with web entrepreneurship.

\section{Conclusion}

Information and communication technologies are meant for all people and women have to be an equal beneficiary to the benefits delivered by the technology, and the products and processes, 
which materialise from their use. Women require information mainly pertaining to educational opportunities and research, career advancement, matrimonial, health as well as infant care facilities, entertainment, legal provisions against sexual harassment, domestic violence and social injustice. Cyber feminism focuses on the impact of new technologies on the lives of women and the subtle gendering of techno culture in daily life. Feminists utilise the web as a crucial tool for connecting women all over the world in order to overcome gender and racial privilege. A nation that desires advancement and development must not afford to disregard capacity building and empowerment of women. Cyberspace and the Internet provide access to same information to women as it is available to men. We must involve women in the technology development lifecycle, since they are agents of change as well as beneficiaries. The gender divide in cyberspace handling is determined by cultural barriers and socio-economic obstacles which are really complex and moreover affect women negatively. The gender disparity in Internet usage is improbable to close down naturally on its own, without the targeted involvement of the policymakers and other stakeholders. Financial support should be provided by the government, so that women get easy access to the vast knowledge on the Internet and nurture each other's ideas. It is imperative to identify that though there is no 'silver bullet' to overcome these obstacles or difficulties, there are n number of actions that stakeholders of ICT can take at present, which possibly will augment women's Internet access and usage. The image of technology needs to change to incorporate a female view. In some markets, escalating women's Internet usage could be the difference amid stable and growing revenues and shrinking or stagnant revenue progression. As technology has no gender barriers, cyber feminists comprehend the neo technologies as indispensable to the new social and economic reorganization that appears to affect the situation of women in a constructive way.

\section{References}

Bimber, Bruce. (2000). Measuring the gender gap on the Internet. Social Science Quarterly, 81, 868-876.

Bellman, Eric. https://blogs.wsj.com/briefly/2016/10/13/tech-sexism-the-missing-indian-women-of-theinternet-the-numbers/ (Retrieved on 4 August 2017).

Burchell, Julia. Connected, Women Gain Strength. https://www.gsma.com/mobilefordevelopment/programme/connected-women/connected-womengain-strength (Retrieved on 18th May 2017).

Cater-Steel, Aileen \& Emily Cater. (2010). Women in Engineering, Science and Technology: Education and Career Challenges. New York: IGI Global.

Channa, Subhadra. (2004). Encyclopedia of Feminist Theory, Volume 1. New Delhi: Genesis Publishing Pvt. Ltd.

Colley, Ann, and Maltby John. (2008). Impact of Internet on Men and Women. Computers in Human Behavior, Elsevier, 24, 2005-2014

Gamble, Sarah ed.(2004). The Routledge Companion to Feminism and Post-feminism. London: Routledge.

Gomez Christine. (1991). "New Horizon : Exploring the possibilities of Feminist Literary Criticism on Indian Writing in English", Indian Women Novelist, Ed. R. K. Dhawan, Set I : Vol.1, New Delhi: Prestige Books, pp.84-103.

Internet usage in India - Statistics and facts. https://www.statista.com/topics/2157/internet-usage-in-india. (Retrieved on 18th May 2017) 
Kuah-Pearce, Khun Eng.(2008) Chinese Women and the Cyberspace. Amsterdam: Amsterdam University Press, p.11.

Millar, Melanie S. (1998). Cracking the Gender Code: Who Rules the Wired World? Toronto: Second Story Press.

Mukherjee, Indranil. Gender Imbalance. https://scroll.in/article/816892/indias-internet-population-isexploding-but- women-are-not-logging-india (Retrieved on 18th May 2017).

Nair, Sudha. http://www.wisat.org/programs/national-assessments-on-gender-sti/ (Retrieved on 10 August 2017)

Samantaray, Swati. (2012). Reflections of Feminism and Existentialism in Shobha De's Novels. Journal of Literature E Aesthetics, Vol. 12, No.1, 63-67.

Singh, Sushila. (1991). "Recent Trends in Feminist Thought: A Tour de Horizon". Feminism and Recent Fiction in English. Ed. Sushila Singh. New Delhi: Prestige Books.

Vesna Dragojlov. 'Cyberfeminism'. http://www.uat.edu/academics/cyberfeminism.aspx. Retrieved on 17th May 2017.

Wajcman, Judy. (2013). TechnoFeminism. UK: John Wiley \& Sons.

Wall, David S. (2007). Cybercrime: The Transformation of Crime in the Information Age. U. K.: Polity Press.

Dr. J R Mohanty is currently working with KIIT University, Bhubaneswar, Odisha as a Professor in the School of Computer Applications. He earned his Ph.D. Degree in Computer Science from Utkal University, Bhubaneswar. He has more than 21 years of teaching experience in both U.G. and P.G. levels. He is a life member of The Indian Society for Technical Education and Indian Science Congress Association. He is actively engaged in research work. He has authored books and has to his credit innumerable publications in reputed International/Scopus indexed journals and in International Conference proceedings. He has edited books published by Springer and IJCA volume as international conference proceedings. He has also authored two book chapters and reviewed a couple of books of Tata McGraw Hill. His research interests include Queuing Theory, Computational Intelligence, and Cloud Computing.

Dr. Swati Samantaray is currently working with KIIT University, Bhubaneswar as an Associate Professor. She has 20 years of teaching experience. She is actively engaged in research work. Dr. Swati has authored a number of books and has to her credit innumerable publications in reputed International/Scopus indexed journals. She was also associated with Tata Consultancy Services as a faculty of soft skills. Her field of interests are mysticism, eco-criticism, feminism, existentialism, folklore, dystopia, diaspora literature, literature of the marginal. 